\title{
Role of nitric oxide in orthodontic tooth movement (Review)
}

\author{
TONG YAN ${ }^{1,2 *}$ YONGJIAN XIE ${ }^{3 *}$, HONGWEN HE $^{2}$, WENGUO FAN ${ }^{2}$ and FANG HUANG ${ }^{1}$ \\ ${ }^{1}$ Department of Pediatric Dentistry, Hospital of Stomatology, Sun Yat-sen University, Guangzhou, Guangdong 510055; \\ ${ }^{2}$ Guangdong Provincial Key Laboratory of Stomatology, Guanghua School of Stomatology, Sun Yat-sen University, \\ Guangzhou, Guangdong 510080; ${ }^{3}$ Department of Orthodontic Dentistry, Hospital of Stomatology, \\ Sun Yat-sen University, Guangzhou, Guangdong 510055, P.R. China
}

Received March 22, 2021; Accepted June 8, 2021

DOI: $10.3892 / \mathrm{ijmm} .2021 .5001$

\begin{abstract}
Nitric oxide (NO) is an ubiquitous signaling molecule that mediates numerous cellular processes associated with cardiovascular, nervous and immune systems. NO also plays an essential role in bone homeostasis regulation. The present review article summarized the effects of $\mathrm{NO}$ on bone metabolism during orthodontic tooth movement in order to provide insight into the regulatory role of $\mathrm{NO}$ in orthodontic
\end{abstract}

Correspondence to: Professor Fang Huang, Department of Pediatric Dentistry, Hospital of Stomatology, Sun Yat-sen University, 56 Lingyuan Xi Road, Guangzhou, Guangdong 510055, P.R. China

E-mail: hfang@mail.sysu.edu.cn

Dr Wenguo Fan, Guangdong Provincial Key Laboratory of Stomatology, Guanghua School of Stomatology, Sun Yat-sen University, 74 Zhongshan Road 2, Guangzhou, Guangdong 510080, P.R. China

E-mail: fanweng@mail.sysu.edu.cn

${ }^{*}$ Contributed equally

Abbreviations: NO, nitric oxide; cGMP, cyclic guanosine monophosphate; NOS, nitric oxide synthase; L-arg, L-arginine; nNOS, neuronal NOS; eNOS, endothelial NOS; iNOS, inducible NOS; sGC, soluble guanylyl cyclase; PKG, cGMP-dependent protein kinases; PDE, phosphodiesterase; PDL, periodontal ligament; CGRP, calcitonin gene-related peptide; M-CSF, monocyte/macrophage colony-stimulating factor; RANKL, receptor activator of nuclear factor- $\kappa \mathrm{B}$ ligand; OPG, osteoprotegerin; IL, interleukin; TNF, tumor necrosis factor; PGE2, prostaglandin E2; cAMP, cyclic adenosine monophosphate; MMPs, matrix metalloproteinases; Runx2, transcription factor runt-related transcription factor 2; BMP, bone morphogenetic protein; TGF, transforming growth factor; MAPK, mitogen-activated protein kinase; HIF, hypoxia-inducible factor; VEGF, vascular endothelial growth factor; FSS, fluid shear stress; ECM, extracellular matrix; Cx, connexin; FAK, focal adhesion kinase; ODQ, 1H-(1,2,4)oxadiazolo-(4,3-a)quinoxalin-1-one; ERK, extracellular signal-regulated kinase; PI3K, phosphoinositide 3-kinase; Akt, protein kinase B; PFF, pulsed fluid flow; GCF, gingival crevicular fluid; L-NAME, N(G)-nitro-L-arginine methyl ester

Key words: NO, cGMP, orthodontic tooth movement, bone remodeling, osteoblast, osteoclast tooth movement. Orthodontic tooth movement is a process in which the periodontal tissue and alveolar bone are reconstructed due to the effect of orthodontic forces. Accumulating evidence has indicated that $\mathrm{NO}$ and its downstream signaling molecule, cyclic guanosine monophosphate (cGMP), mediate the mechanical signals during orthodontic-related bone remodeling, and exert complex effects on osteogenesis and osteoclastogenesis. NO has a regulatory effect on the cellular activities and functional states of osteoclasts, osteocytes and periodontal ligament fibroblasts involved in orthodontic tooth movement. Variations of NO synthase (NOS) expression levels and NO production in periodontal tissues or gingival crevicular fluid (GCF) have been found on the tension and compression sides during tooth movement in both orthodontic animal models and patients. Furthermore, NO precursor and NOS inhibitor administration increased and reduced the tooth movement in animal models, respectively. Further research is required in order to further elucidate the underlying mechanisms and the clinical application prospect of NO in orthodontic tooth movement.

\section{Contents}

1. Introduction

2. Orthodontic tooth movement overview

3. Effects of NO on orthodontic tooth movement

4. Conclusions and future perspectives

\section{Introduction}

Nitric oxide (NO) is a water-soluble, gaseous, short-lived free radical molecule that plays multifaceted roles in a broad range of physiological and pathological processes in mammals (1-3). $\mathrm{NO}$ is produced by NO synthase (NOS) as a consequence of the process of L-arginine ( $\mathrm{L}$-arg) conversion into L-citrulline with the participation of oxygen and nicotinamide adenine dinucleotide phosphate. Three isoforms of NOS have been identified: Neuronal NOS (nNOS) and endothelial NOS (eNOS) are constitutively expressed calcium-dependent enzymes, characterized by the rapid production of a small amount of NO; inducible NOS (iNOS) is a calcium-independent enzyme that is upregulated at the transcriptional level during 
inflammation, causing a relatively slow yet increased-output NO production $(2,3)$. The most common target of $\mathrm{NO}$ is soluble guanylate cyclase (sGC), which generates the second messenger cyclic guanosine monophosphate (cGMP) from guanosine-5'-triphosphate within the cell $(4,5)$. cGMP mainly acts on protein kinase $\mathrm{G}$ (PKG) and can be degraded by phosphodiesterase (PDE), such as PDE5, 6 and $9(2,6)$. The effect of $\mathrm{NO}$ on bone mass regulation and bone metabolism has been well investigated and reviewed elsewhere; however, studies on the involvement of NO in orthodontic tooth movement are limited (7-9).

Tooth movement induced by orthodontic force is achieved through bone remodeling, as a result of the sequential transduction of molecular signals and changes in cellular behaviors $(10,11)$. It is of utmost significance to determine the underlying mechanism of orthodontic tooth movement, in order to reduce possible side-effects and shorten the duration of therapy. NO is extensively involved in orthodontic-related biological events, such as aseptic inflammation, mechanical signal transduction and bone remodeling. Furthermore, the regulatory effect of NO on bone remodeling has been demonstrated to be cGMP-related $(12,13)$. In the present review, the regulatory effects of NO on the functional states of related cells and tissues during orthodontic tooth movement, as well as the possible mechanisms involved are discussed, with the aim of providing helpful insight towards the application of effective therapeutic interventions in orthodontics.

\section{Orthodontic tooth movement overview}

Orthodontic tooth movement relies upon periodontal ligament (PDL) and alveolar bone remodeling. The PDL is a dense connective tissue that plugs the tooth to the adjacent alveolar bone $(14,15)$. It contains collagen fiber bundle, blood vessel, nerves, interstitial fluids and multiple cell types, including fibroblasts, osteoclasts, osteoblasts and macrophages $(10,14)$. The alveolar bone consists of bone cells (osteoclasts, osteoblasts and osteocytes) and the mineralized matrix $(14,16)$. The force applied to the tooth triggers cell-signaling cascades in the PDL and the alveolar bone, leading to tissue remodeling and tooth movement $(11,17)$.

Orthodontic tooth movement can be organized into three phases: i) The initial phase; ii) lag phase; and iii) post-lag phase (18). In the initial phase, tooth movement occurs due to the deformation of PDL and tooth displacement within the alveolar socket 24 to $48 \mathrm{~h}$ after the application of force to the teeth. The lag phase follows the initial phase, during which little or no tooth movement is observed due to PDL hyalinization in the compression region. This phase lasts 20-30 days. Following the removal of necrotic tissue by macrophages, tooth movement resumes in the post-lag phase $(19,20)$. This phase usually occurs 40 days after the initial application of force.

Cellular and molecular mechanisms of orthodontic tooth movement

Pressure side: Osteoclasts and bone resorption. The pressure-tension theory describes orthodontic tooth movement as an outcome of bone resorption in the compression region and bone formation in the tension region (21). On the pressure side, the reduction of blood flow and the distortion of nerve endings in PDL may cause hypoxia and the release of vasoactive neurotransmitters, including substance $\mathrm{P}$, calcitonin gene-related peptide (CGRP), and vasoactive intestinal polypeptide. As a result, vasodilatation and the aggregation of circulating leukocytes, monocytes, macrophages, lymphocytes and mast cells has been observed (22-26). Growth factors, chemokines and other cytokines also contribute to these processes $(23,27,28)$.

Osteoclasts are multinucleated cells, that initially differentiate from multipotential hematopoietic precursors in the monocyte/macrophage lineage, upon macrophage-colony stimulating factor (M-CSF) and receptor activator of nuclear factor- $\kappa \mathrm{B}$ ligand (RANKL) stimulation, which are secreted primarily by cells of the osteoblast lineage (29-35). M-CSF promotes the proliferation, adhesion and migration of osteoclast precursor cells (36-38). RANKL promotes the fusion, differentiation and bone resorptive function of osteoclasts through the activation of RANK on the surface of osteoclast precursors $(33,39,40)$. OPG, a decoy receptor for RANKL, suppresses osteoclastogenesis through the blockage of the RANK/RANKL signaling pathway $(41,42)$.

The aseptic inflammatory response caused by orthodontic forces is indispensable for tooth movement $(11,43)$. Interleukin (IL)-1 $\beta$, IL-6, tumor necrosis factor (TNF)- $\alpha$ and prostaglandin E2 (PGE2) can induce the release of RANKL and MCS-F to stimulate osteoclast precursor differentiation (41,44-47). In addition to the enhancement of osteoclastogenic factor expression, TNF- $\alpha$ also activates osteoclast precursors directly through it binding to TNF receptor $(32,48,49)$. PGE2 enhances the bone-resorbing activity of osteoclasts through the increase of intracellular cyclic adenosine monophosphate (cAMP) levels or the partial mediation of TNF- $\alpha$ (50). Mature osteoclasts occupy small cavities termed Howship's lacunae, in which hydrogen ions and proteolytic enzymes are released, including cathepsin $\mathrm{K}$ and matrix metalloproteinases (MMPs), in order to degrade the bone matrix $(39,51,52)$. When the magnitude of the force decreases, osteoclasts become inactive and detach from the bone (53).

Tension side: Osteoblasts and bone formation. Bone deposition induced by osteoblasts presents is the predominant event on the tension side $(20,54)$. Derived from bone marrow mesenchymal stem cells, osteoblasts secrete an organic matrix known as the osteoid, which is then incorporated further into the mature bone (55). During bone formation, some osteoblasts transform into bone lining cells on the bone surface, or osteocytes embedded in the bone matrix. Osteocytes are connected and communicate through cytoplasmic processes in tiny canals, called canaliculi $(56,57)$.

Transcription factor runt-related transcription factor 2 (Runx2), also known as ore-binding factor subunit alpha-1 (Cbfa1) and the Wnt/ $\beta$-catenin pathway provide the initial and essential stimulus for osteoblast differentiation $(34,58)$. Bone morphogenetic protein (BMP), as a member of the transforming growth factor $\beta$ (TGF- $\beta$ ) superfamily, induces the differentiation of osteoprogenitor cells and promotes osteoblast function through the stimulation of Runx 2 expression via the small mother against decapentaplegic or p38 
mitogen-activated protein kinase (MAPK) pathways (59-62). In addition, TGF- $\beta$ also suppresses bone resorption activity through the upregulation of the tissue inhibitor of metalloproteinases expression $(43,63)$. IL-10 induces an overall reduction in RANK signaling, through the facilitation of OPG expression and the reduction of RANKL production $(43,64,65)$.

Regional hypoxia caused by orthodontic force induces hypoxia-inducible factor (HIF)-1 expression and upregulates the transcription of vascular endothelial growth factor (VEGF) in PDL fibroblasts and osteoblasts. VEGF is associated with osteogenic differentiation and matrix mineralization under the regulation of BMP, corroborating the concept that angiogenesis and osteogenesis are combined $(66,67)$. Furthermore, HIF-1 and VEGF also stimulate osteoclast differentiation via the upregulation of RANKL, contributing to the combination of bone resorption and bone formation (68-70).

Some molecules that regulate the response of PDL fibroblasts to the orthodontic forces have been identified in previous studies, such as CC chemokine receptor 5 (CCR5) and CCR5 ligands axis (71), relaxin (Rln) and Rln family peptides (Rxfps) axis (72), and secretory leucocyte peptidase inhibitor (73). The expression levels of these molecules were upregulated in the PDL, due to compression and tension force; however, their downstream effects were different. Another consequence was the upregulation of the osteoclastogenesis-relating factors, including RANKL, MCSF and MMPs, on the compression side, and osteoclast activity inhibiting factors, including Runx2, IL-6, and IL-12, that may induce osteoblast differentiation on the tension side.

Mechanotransduction: Osteocytes and fibroblasts. Osteocytes are critical for the transduction of mechanical stimuli into biochemical signals (74-76). When a force is exerted on the tooth, the squeeze of the interstitial fluid causes fluid shear stress (FSS) in the extracellular matrix (ECM) (77). The fluid flow hypothesis describes the response of osteocytes to FSS as an essential mechanism during orthodontic treatment. FSS stimulates an increase in the intracellular calcium concentration and the release of intercellular molecules in osteocytes through the activation of integrin, a transmembrane protein that connects ECM macromolecules to the internal cytoskeleton (78-80). The FSS-related up-regulation of NO, PGE2, TFG- $\beta$, and insulin-like growth factor alters the osteocyte metabolic state and osteoblast/osteoclast functions $(81,82)$. Gap junctions formed by connexin $(\mathrm{Cx})$ also participate in the osteocyte-osteoblast communication $(83,84)$. For example, $\mathrm{Cx}$ is involved in the release of PGE2, which enhances Runx2 DNA binding activity through the simultaneous activation of the cAMP/cAMP-dependent protein kinase and MAPK pathways and the subsequent stimulation of RANKL expression in osteoblasts (85-88).

The inhibitory effect of osteocytes on osteoblastic activity can be induced by the secretion of sclerostin, which antagonizes BMP effect and blocks canonical Wnt signaling (89-91). Osteocytes regulate osteoclastic differentiation via the alternation of major osteoclast regulators, namely RANKL and M-CSF (92-94). Moreover, osteocyte apoptosis induction is an important event in the recruitment and differentiation of osteoclasts (95-97). These findings confirm that osteocytes play a key role in the response to biomechanical stimuli and controlling bone remodeling by coordinating the activity of osteoblasts and osteoclasts.

Fibroblasts are involved in mechanosensation and mechanotransduction in connective tissues. The application of mechanical stretching activates integrin and causes conformational changes in focal adhesion kinase (FAK), inducing a signaling cascade that modulates cytoskeletal dynamics and gene transcription in fibroblasts $(98,99)$.

\section{Effects of NO on orthodontic tooth movement}

Expression of NO in bone tissue. Three NOS isoforms in total are expressed in osteoblasts, osteoclasts and osteocytes (100-102). iNOS and eNOS are expressed in human PDL stem cells $(103,104)$. Previous studies revealed the presence of sGC and cGMP in mouse bone marrow macrophages (105), osteoclasts (105-107), and osteocytes (108). Davidovitch et al $(109,110)$ performed immunohistochemistry (IHC) on alveolar bone sections obtained from cats and revealed that cGMP expression was increased in the PDL fibroblast cells stained intensely for; however, most cGMP expression was not detected through IHC staining in osteoblasts. However, cGMP expression increased due to the subjection of the alveolar bone to mechanical force $(111,112)$. The application of electric currents to the bone, also led to the upregulation of cGMP in osteoblast and PDL fibroblast cells, accompanied by bone deposition near the cathode (113-115). Since a piezoelectric current can be generated by mechanical stress, the above findings suggest that NO/cGMP is an important signaling pathway, which mediates bone cell response to mechanical force (116).

Role of NO in cells associated with orthodontic tooth movement. Mounting evidence indicates that NO regulates multiple cellular behaviors related to orthodontic movement (Fig. 1 and Table I).

Osteoclasts. A number of studies have demonstrated that NO exerts biphasic effects on osteoclast formation and function. In several cases, $\mathrm{NO}$ promotes osteoclastogenesis and bone resorption. NO mediates pre-osteoclasts fusion through the upregulation of actin cytoskeleton remodeling (117). Histopathological studies have demonstrated that osteoclasts, Howship's lacunae and new capillaries were increased in rats that received an injection of the NO precursor L-arg during tooth movement (118-120).

iNOS is an important regulator of osteoclast differentiation under bacterial infection-induced inflammatory conditions (121-123). iNOS was previously found to mediate alveolar bone loss and periapical infectious bone resorption following the oral administration of Porphyromonas gingivalis (124) or lipopolysaccharide (122). In another study, histochemical analysis revealed that the osteoclast number in iNOS(-/-) mice in comparison to wild-type mice was considerably decreased (123). Tooth eruptions are similar to tooth movement in terms of monocyte recruitment and osteoclast differentiation. Evidence indicates that increased levels of iNOS are associated with a greater number of osteoclasts in mice with accelerated tooth eruption, indicating that iNOS may be a bone resorption modulator candidate (125). 


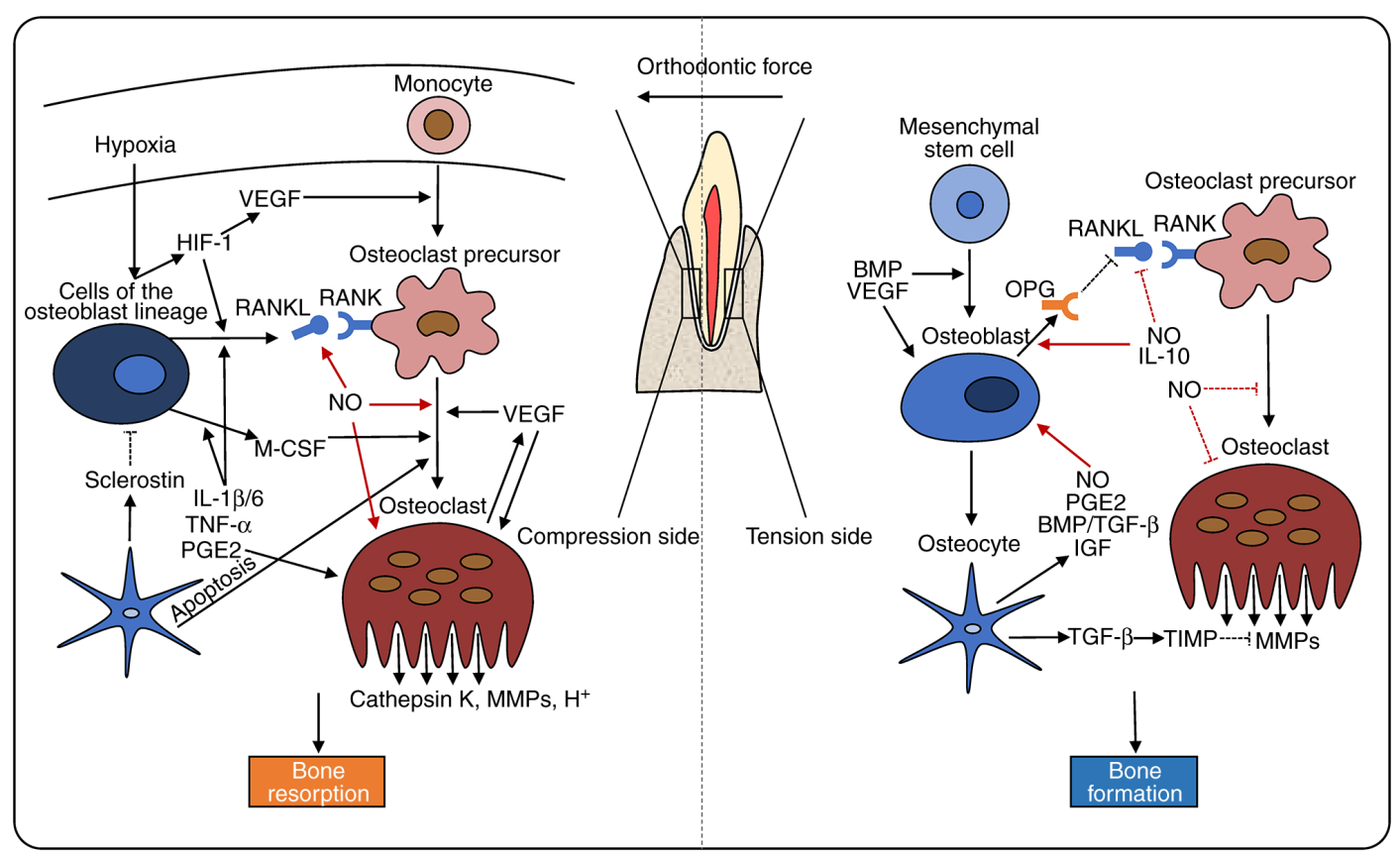

Figure 1. A schematic representation of bone remodeling and NO regulation during orthodontic tooth movement at the compression and tension sides. After orthodontic force is applied to the teeth, bone remodeling in the compression region mainly manifests as osteoclastogenesis and bone resorption, while that in the tension region presents as osteogenesis and bone formation. The regulation of related factors on bone remodeling is indicated by black arrows. NO regulation of osteoclasts and osteoblasts differentiation is indicated by red arrows. HIF-1, hypoxia-inducible factor-1; VEGF, vascular endothelial growth factor; RANKL, receptor activator of nuclear factor- $\mathrm{kB}$ ligand; RANK, receptor activator of nuclear- $\mathrm{\kappa B}$; M-CSF, macrophage-colony stimulating factor; IL-1 $\beta / 6$, interleukin-1 $\beta / 6$; TNF- $\alpha$, tumor necrosis factor- $\alpha$; PGE2, prostaglandin E2; MMPs, matrix metalloproteinases; BMP, bone morphogenetic protein; OPG, osteoprotegerin; TGF- $\beta$, transforming growth factor- $\beta$; IGF, insulin-like growth factor; TIMP, tissue inhibitor of metalloproteinases.

As previously demonstrated, M1-like macrophage polarization and an enhanced M1/M2 macrophage ratio increase the number of osteoclasts in rats or mice, accompanied by an increase in M1 macrophage marker expression (TNF- $\alpha$ and iNOS) on the compression side, during tooth movement $(126,127)$. TNF- $\alpha$ stimulates the survival of differentiated osteoclasts through the induction of iNOS-dependent NO generation (128). In the rheumatism inflammatory environment, the TNF- $\alpha$ promoting effect on alveolar bone resorption is partly mediated through the activation of iNOS and the resulting production of NO (129).

It has been observed that the promoting effect of iNOS on osteoclasts is mediated through the NO/cGMP pathway. Kaneko et al (105) revealed that 8-nitro-cGMP, a NO-dependent derivative of cGMP in mammals, increased RANKL mRNA expression, and enhanced osteoclast differentiation. The reduction in cGMP levels due to the inhibition of NOS caused RANKL-induced osteoclast differentiation suppression.

By contrast, evidence has revealed an inhibitory effect of NO on osteoclasts at low concentrations. NO has been reported to increase osteoclast and osteoclast precursor cell apoptosis (101,130-132). A novel NO donor, nitrosyl-cobinamide (NO-Cbi), has been found to reduce the RANKL/OPG gene expression ratio or directly inhibit osteoclast differentiation in vitro and in vivo (133). Nicorandil, an agent that can increase NO production in osteoclasts, was previously shown to suppress osteoclast differentiation via activating sGC (134). NO causes osteoclast detachment and downregulates osteoclast bone-resorbing activity via the NO/cGMP/PKG pathway in vitro $(101,107,135-137)$. Of note, the selective inhibition of iNOS was previously found to markedly promote bone resorption in vivo. In an iNOS(-/-) mouse model of apical periodontitis, enhanced osteoclast differentiation and increased bone resorption were observed in comparison with the control group, accompanied by increased IL- $1 \beta$, TNF- $\alpha$, RANK, RANKL and monocyte chemoattractant protein-1 (MCP-1) levels $(138,139)$. These results suggest that NO deficiency is associated with an imbalance in the host inflammatory response, resulting in severe bone loss.

Moreover, iNOS exerts an inhibitory effect on osteoclast differentiation through other pathways. Zheng et al (140) demonstrated that iNOS was a RANKL-induced autocrine negative feedback inhibitor of RANKL-mediated osteoclastogenesis. RANKL triggered iNOS expression and NO release, and subsequently inhibited RANKL-induced osteoclast formation in a cGMP-independent manner.

The inconsistent effects of NO on osteoclastogenesis may be attributed to the differences in NO synthesis quantity, cell types and development states. NO action is also affected by the cytokines in the microenvironment. Multiple factors influence the downstream signaling of $\mathrm{NO}$, and further studies are required to elucidate the specific mechanism of $\mathrm{NO}$ regulation.

Osteoblasts. NO is also involved in the bidirectional regulation of osteoblasts. Decreased NO concentrations promote osteoblast proliferation, differentiation and survival (133,141-143). Mineralized nodule formations and mRNA expression levels of osteoblastic genes, such alkaline phosphatase, osteocalcin and collagen-1 genes, have been shown to be enhanced by NO donors and 8-Br-cGMP, an analog of cGMP (141-143). This effect was blocked by $1 \mathrm{H}-(1,2,4)$ oxadiazolo-(4,3-a)quinoxalin-1-one (ODQ), a competitive blocker that prevents sGC 


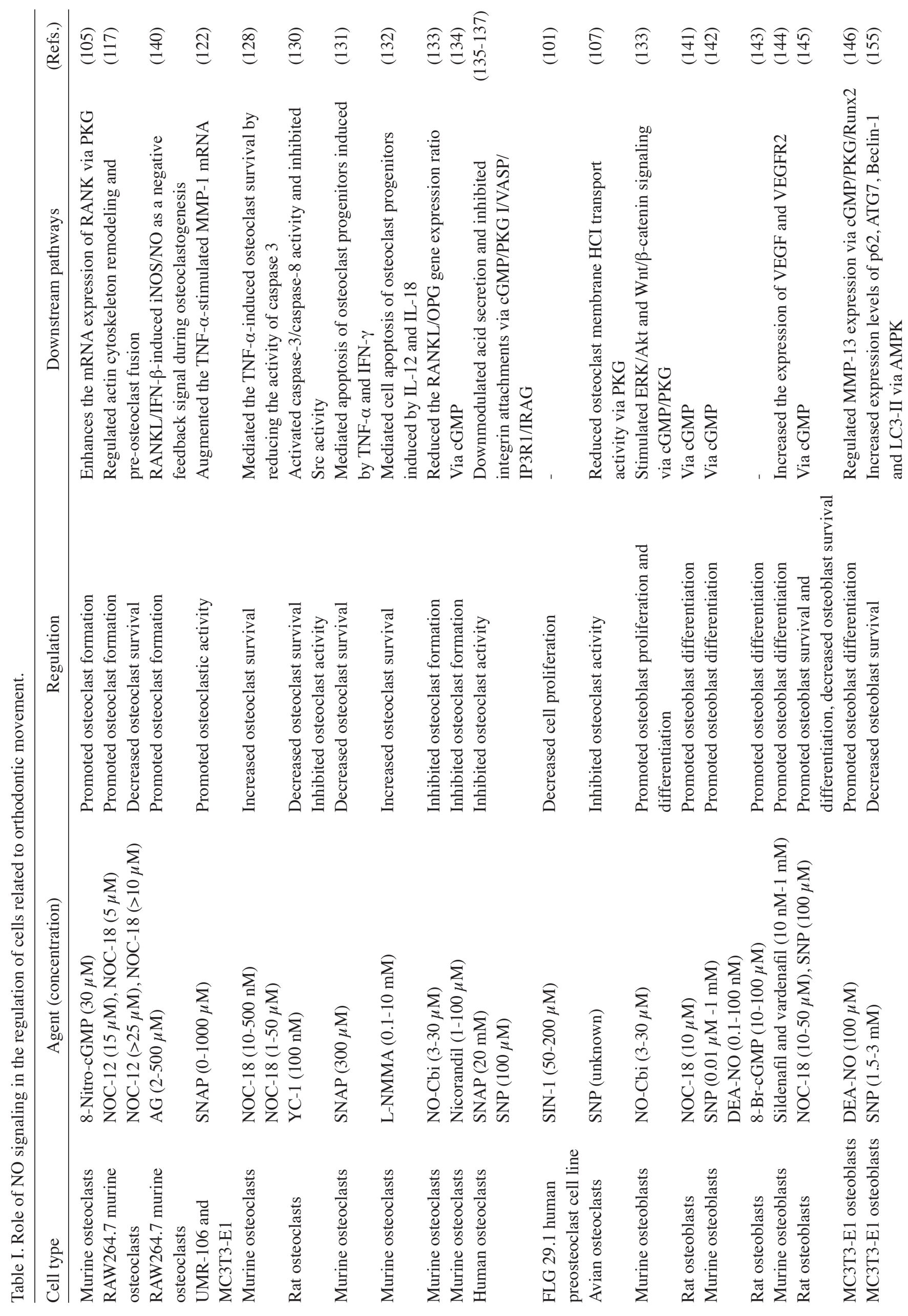


activation and lowers cGMP/PKG activity. It has been recently stated that PDE5 inhibitors, which can significantly increase intracellular cGMP levels, induce osteoblast differentiation and enhance bone regeneration in osteopenic mice via the cGMP/VEGF pathway (144). These findings further support the involvement of $\mathrm{NO} / \mathrm{cGMP} / \mathrm{PKG}$ pathway in the regulation of osteoblast activity $(133,143,145)$.

Increased iNOS expression and NO levels have been observed during osteoblast differentiation in vitro. iNOS has been reported to mediate the regulation of Runx2 translocation and downstream events (146). In eNOS knockout mice, osteoblast growth has been shown to be inhibited (147). Evidence suggests that eNOS activation promotes cell survival and enhances osteoblastic gene expression in osteoblasts via pathway cascades involving Src/extracellular signal-regulated kinase (ERK), phosphoinositide 3-kinase (PI3K)/protein kinase B (Akt) and Wnt/ $\beta$-catenin $(148,149)$.

NO mediates the action of several local and systemic factors, including mechanical stimulation, hormones and other signaling molecules in osteoblasts $(13,150)$. It has also been revealed that 1,25-dihydroxyvitamin $\mathrm{D}(3)$ regulates bone mass via the upregulation of iNOS expression and NO production (151). CGRP has been found to promote mandibular bone fracture healing in vivo and stimulate the eNOS activity through the increase of intracellular calcium concentrations in osteoblasts in vitro $(152,153)$. Furthermore, it has been observed that $17 \beta$-estradiol, a major endogenous estrogen, may promote eNOS expression and osteoblast differentiation through Akt phosphorylation in a dose-dependent manner (154). It has been previously demonstrated that the bone-protective effects of estrogen rely upon the NO/cGMP pathway $(147,150)$. High concentrations of NO negatively impact osteoblast proliferation and survival (145). NO simultaneously induces cell death and autophagy in osteoblasts (155).

Osteocytes and PDL fibroblasts. The effect of NO on osteocytes is similar to that of osteoblasts. Parathyroid hormone and $17 \beta$-estradiol levels increase the expression of cGMP expression in osteocytes (108). Cinaciguat, an activator of sGC that has been declared as a potential drug target for osteoporosis, was previously found to reverse osteocyte apoptosis and enhance bone formation in mice subjected to ovariectomy (156). NO/cGMP/PKG signaling mediated $17 \beta$-estradiol anti-apoptotic effect on osteocytes through either the activation of the pro-survival kinases, ERK and Akt, mediated by type II PKG, or direct phosphorylation of protein related to cell death by type I (PKG) $(157,158)$. However, inflammation-induced iNOS activation and elevated concentrations of $\mathrm{NO}$ can lead to osteocyte apoptosis (132).

$\mathrm{NO} / \mathrm{cGMP} / \mathrm{PKG}$ signaling has been shown to regulate human PDL fibroblast proliferation and differentiation, with the involvement of MAPKandnuclearfactor $\kappa$-light-chain-enhancer of activated B cells pathways (103,159-161). However, the effect of NO on cell proliferation in PDL has not yet been fully clarified. A previous study revealed that NO did not influence PDL stem cell proliferation (103). In other studies, it has been revealed that exogenous NO inhibits proliferation and induces apoptosis of PDL fibroblasts $(159,162)$. This discrepancy could be attributed to differences in the cellular differentiation levels and varying applied agent concentrations. 
The PDL and the alveolar bone are developed from the dental follicle during tooth development. The literature was reviewed and it was observed that studies of $\mathrm{NO}$ regulation impact upon the dental follicle during tooth development has not been reported yet, to the best of our knowledge. It was surmised that the exploration of the underlying mechanism of NO on the development of the PDL and alveolar bone may provide novel insights into the role of $\mathrm{NO}$ in the tissue remodeling observed during orthodontic tooth movement.

NO signaling in bone mechanotransduction $\mathrm{NO}$ is a factor that mediates early cellular response to applied mechanical forces in the PDL and bone (Fig. 2) $(13,163,164)$. NO synthesis in osteoclasts $(165)$, osteoblast $(116,151,163,165-167)$, osteocytes $(164,168)$, PDL fibroblasts (169), fibroblasts (170), and dental pulp cells $(171,172)$ increased following the application of mechanical loading, pulsed fluid flow (PFF), electrical stimulation, or pulsed electromagnetic field stimulation.

The mechanical loading-induced activation of the Wnt/ $\beta$-catenin pathway is an important signaling event in osteoblasts, osteocytes, and PDL fibroblasts, and is mediated by a NO-dependent mechanism involving the FAK, Src/ERK and PI3K/Akt signaling pathways $(169,173,174)$. PFF increases NO synthesis in osteoblasts, resulting in PKG II-dependent activation of Src and PI3K-dependent phosphorylation of Akt. The nuclear translocation of $\beta$-catenin is induced and the gene expression of c-fos is upregulated, initiating a proliferative response in mechanically stimulated osteoblasts (175-177). When the osteoblast and osteocyte cytoskeleton system of disrupted, PFF-induced NO production is affected (178).

PFF induces the release of multiple soluble factors that promote osteogenesis and inhibits bone resorption. This process is partially dependent on the generation of NO (74,179-181). PFF-induced NO inhibited osteocyte apoptosis through the downregulation of B-cell lymphoma-2 (Bcl-2) and caspase-3 (182). NO also modulates mechanically induced VEGF expression, contributing to angiogenesis during bone remodeling $(183,184)$.

The main NOS isoform that produces NO in osteoblasts and osteocytes under the mechanical force action has not yet been elucidated. The activation of eNOS is associated with the phosphorylation or dephosphorylation at several functional sites on eNOS, which may be induced by FSS, estrogens, VEGF and insulin (185-187). Several studies have revealed that FSS-induced NO production is attributed to the calcium-dependent eNOS activation in bone cells $(13,185,188,189)$. It has been revealed that the occlusal force led to iNOS and eNOS increased expression in hypofunctional and normal PDL fibroblasts $(100,104)$.

Additionally, it has been suggested that eNOS may be not indispensable for mechanically-induced $\mathrm{NO}$ synthesis in cultured osteoblasts or eNOS (-/-) mice $(190,191)$. It has also been mentioned that ultrasound-induced bone formation may be mediated through nNOS and iNOS upregulation in osteoblasts $(82,163,192,193)$. Furthermore, osteopontin has been shown to suppress the osteoblast response to ultrasound by inhibiting the expression of nNOS and iNOS through FAK downregulation (194). This inconsistency may be explained in view of the possibility of an alternative way of NO production induction by other NOS isoforms and through a non-enzymatic NO production manner (including reduction of nitrite and denitrosylation of some proteins), in case a specific NOS isoform is absent (195-197). The aforementioned ultrasound results can only prove the role of nNOS or iNOS in ultrasound-induced promotion on osteoblasts; however, those results do not contradict the involvement of eNOS.

These findings suggest that NO plays a complex role in mechanotransduction under stress in the periodontal tissue, and further research on this topic is required.

Effects of NO in orthodontic tooth movement. Many studies have focused on the differential expression of NOS isoforms between areas of compression and tension during orthodontic tooth movement. Experiments in rats revealed that the changes in NOS activity in the PDL could be detected as soon as $1 \mathrm{~h}$ after teeth were subjected to orthodontic force (198). The increased expression of iNOS on the pressure side and eNOS on the tension side was observed $24 \mathrm{~h}$ after initiating mechanical loading, while increased nNOS expression mainly occurred after 3 h (199). An increase of iNOS-positive osteocytes in the compression area was detected $6 \mathrm{~h}$ after force application, while eNOS-positive osteocytes in the tension area increased after $24 \mathrm{~h}$ (200). As indicated above, it is generally accepted that iNOS dominates bone resorption at the compression site while eNOS mediates the osteogenic effect in the tension area $(200,201)$.

The availability of studies related to the changes in NO levels in human periodontal tissues before and after orthodontic treatment is limited. Analysis of gingival tissue collected from orthodontic patients revealed that eNOS and iNOS levels increased dramatically 2 weeks after the appliance placement (202). A variety of biomarkers in gingival crevicular fluid (GCF) are often analyzed, in order to facilitate the improvement of clinical treatment. In various studies, many of which recent, it has been mentioned that NO expression levels in GCF is related to orthodontic treatment (203-206). Ford et al (203) revealed that NO concentration in GCF on the compression side of the central incisor increased significantly $1 \mathrm{~h}$ after the application of fixed orthodontic appliances. In patients who received rapid maxillary expansion therapy, the NO levels in GCF were elevated on day 1 and 10 and were still elevated after 3 months of retention $(204,205)$. However, no significant difference was detected in NO levels in GCF on the tension side, during the above treatment. These results further support the different regulatory effects of NO on the tension and pressure side, which are related to the presence of different NOS isoforms on different sides.

The role of NO in orthodontic treatment has also been confirmed in animal experiments. Tooth movement was markedly promoted in rats that received L-arg injection, whereas a significant reduction of tooth movement was observed in the L-NAME (eNOS inhibitor) group. Histological results also revealed a greater number of osteoclasts in the group with greater tooth movement $(119,120,207)$. Notably, decreased force-induced root resorption was noted in this group in comparison with the control group, although the number of osteoclasts increased in the L-arg injection group (119).

Influences of $\mathrm{NO}$ and oral microbiota on the orthodontic tooth movement are also notable. In addition to being synthesized by the body, NO can be produced by oral 


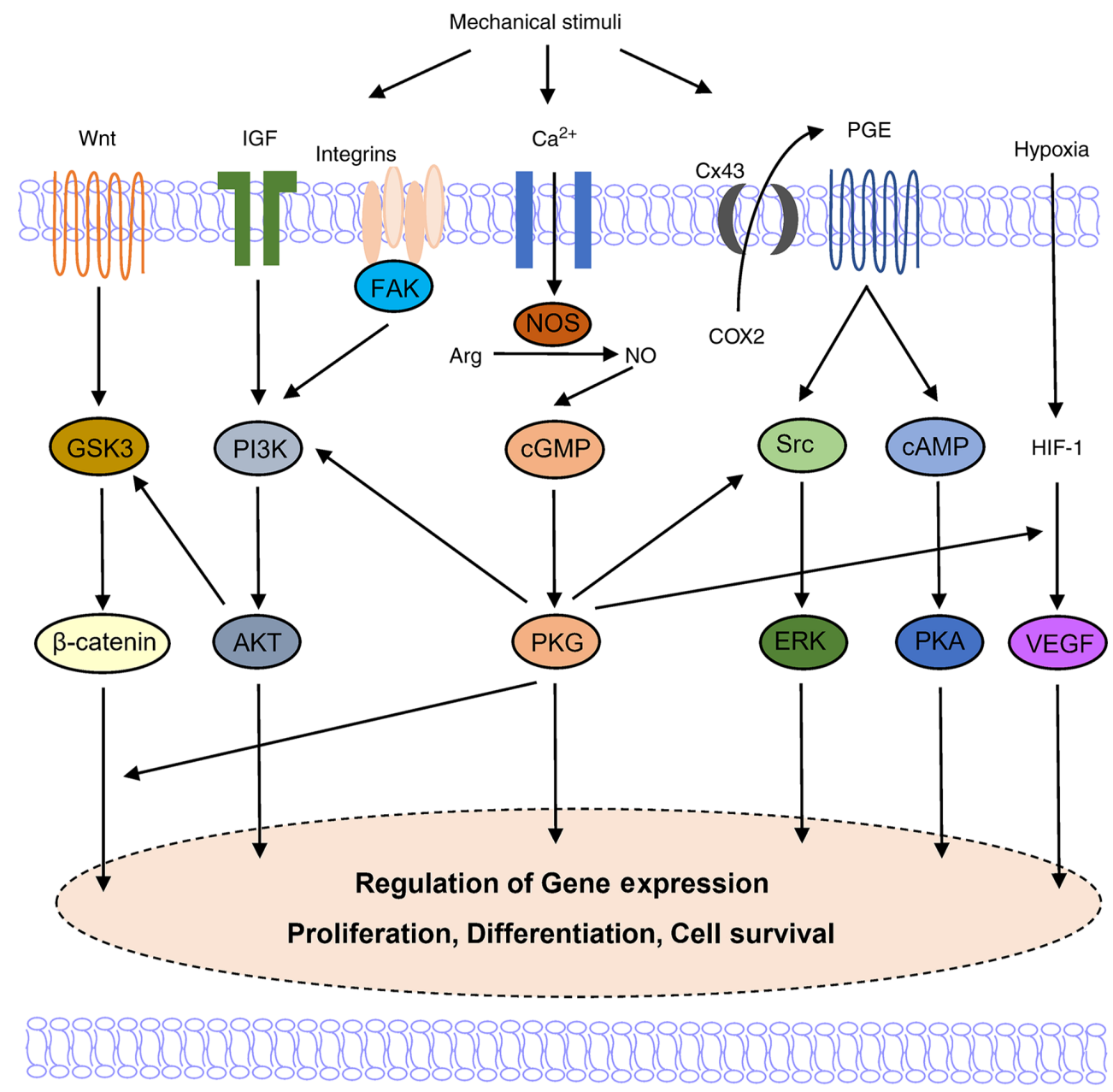

Figure 2. A schematic representation of signaling pathways activated by mechanical stimuli and mechanically-induced NO regulation in osteoblastic cells. Mechanical loads induce signal transduction through the activation of several signaling pathways, resulting in the increased expression of pro-osteogenic factors, thus providing an environment which contributes to osteoblast proliferation and differentiation. NO/cGMP/PKG pathway is widely involved in the regulation of the above signaling pathways, indicating its important role in the mechanical transduction process. GSK3, glycogen synthase kinase 3; IGF, insulin-like growth factor; PI3K, phosphoinositide 3-kinase; Akt, protein kinase B; NOS, nitric oxide synthase; Arg, arginine; NO, nitric oxide; cGMP, cyclic guanosine monophosphate; PKG, protein kinase G; Cx43, connexin 43; COX-2, cyclooxygenase-2; PGE2, prostaglandin E2; ERK, extracellular signal-regulated kinase; cAMP, cyclic adenosine monophosphate; PKA, protein kinase A; HIF-1, hypoxia-inducible factor 1; VEGF, vascular endothelial growth factor.

bacteria under hypoxic conditions through the transformation of saliva nitrate into nitrite (208-210). It has been observed that NO production is upregulated during the deposition of dental plaque (211). In diseases related to plaque accumulation, including periodontitis, an increase in NO levels in both blood and saliva was reported (212-214). Additionally, apart from the oral bacteria-originating NO production, this has also been ascribed to the inflammatory response of the body. It has been previously demonstrated that an enhanced osteoclast formation and accelerated orthodontic tooth movement may be observed in patients with periodontitis (215). It is reasonable to speculate that NO may be involved in this process, but more direct evidence is necessary in order to confirm this (203-207).

\section{Conclusions and future perspectives}

NO is widely involved in the biomechanical response of the periodontium to orthodontic forces. NO exerts dose-dependent and biphasic effects on the functional status and cell fate determination of osteoblasts, osteoclasts, osteocytes, and PDL fibroblasts, and has been shown to promote the proliferation, differentiation, or inhibition of survival and function of cells. As an inflammatory factor and a key second messenger in mechanical transduction, NO is differentially expressed on the tension and compression side during tooth movement, suggesting its complex involvement in bone remodeling. The facilitation of NO precursor and the inhibition of NOS inhibitor in orthodontic tooth movement have also been confirmed in animal experiments. Additional studies are required, in order to evaluate the role and impact of $\mathrm{NO}$ on tooth movement in clinical practice. As NO exerts complex effects on both osteoblastic and osteoclastic activities, the spatiotemporal generation of NO may determine its specific biological effect on bone remodeling. The precise and controlled delivery of NO to periodontal tissue via NO-releasing polymeric nanomaterials may be a promising approach for the acceleration of orthodontic tooth movement.

\section{Acknowledgements}

Not applicable. 


\section{Funding}

The present study was funded by the National Natural Science Foundation of China (nos. 81870737 and 81771098), the Natural Science Foundation of Guangdong Province (no. 2021A1515011779) and Guangdong Financial Fund for High-Caliber Hospital Construction (no. 174-2018-XMZC-0 001-03-0125/D-02).

\section{Availability of data and materials}

Not applicable.

\section{Authors' contributions}

TY, YX and FH conceived the review. TY performed literature search and manuscript writing. YX contributed to the manuscript writing and the preparation of figures and tables. $\mathrm{HH}$, WF and FH revised the manuscript. TY and FH confirm the authenticity of all the raw data. All authors read and approved the final manuscript.

\section{Ethics approval and consent to participate}

Not applicable.

\section{Patient consent for publication}

Not applicable.

\section{Competing interests}

The authors declare that they have no competing interests.

\section{References}

1. Loscalzo J: Nitric oxide and vascular disease. N Engl J Med 333 : 251-253, 1995.

2. Förstermann U and Sessa WC: Nitric oxide synthases: Regulation and function. Eur Heart J 33: 829-837, 837a-837d, 2012.

3. Snyder SH: Nitric oxide. No endothelial NO. Nature 377: 196-197, 1995.

4. Moncada $S$ and Higgs A: The L-arginine-nitric oxide pathway. N Engl J Med 329: 2002-2012, 1993.

5. Sawa T, Ihara H, Ida T, Fujii S, Nishida $M$ and Akaike T: Formation, signaling functions, and metabolisms of nitrated cyclic nucleotide. Nitric Oxide 34: 10-18, 2013.

6. Francis SH, Busch JL, Corbin JD and Sibley D: cGMP-dependent protein kinases and cGMP phosphodiesterases in nitric oxide and cGMP action. Pharmacol Rev 62: 525-563, 2010.

7. van't Hof RJ and Ralston SH: Nitric oxide and bone.Immunology 103: 255-261, 2001.

8. Wimalawansa SJ: Nitric oxide and bone. Ann NY Acad Sci 1192: 391-403, 2010.

9. Evans DM and Ralston SH: Nitric oxide and bone. J Bone Miner Res 11: 300-305, 1996.

10. Li Y, Jacox LA, Little SH and Ko CC: Orthodontic tooth movement: The biology and clinical implications. Kaohsiung J Med Sci 34: 207-214, 2018.

11. Krishnan V and Davidovitch Z: On a path to unfolding the biological mechanisms of orthodontic tooth movement. J Dent Res 88: 597-608, 2009.

12. Kalyanaraman H, Schall N and Pilz RB: Nitric oxide and cyclic GMP functions in bone. Nitric Oxide 76: 62-70, 2018

13. Klein-Nulend J, van Oers RF, Bakker AD and Bacabac RG: Nitric oxide signaling in mechanical adaptation of bone. Osteoporos Int 25: 1427-1437, 2014.

14. Nanci A and Bosshardt DD: Structure of periodontal tissues in health and disease. Periodontol 40: 11-28, 2006.
15. Hassell TM: Tissues and cells of the periodontium. Periodontol 3: 9-38, 1993

16. Bartold PM and McCulloch CA: Information generation and processing systems that regulate periodontal structure and function. Periodontol 63: 7-13, 2013.

17. Antoun JS, Mei L, Gibbs K and Farella M: Effect of orthodontic treatment on the periodontal tissues. Periodontol 74: 140-157, 2017.

18. Burstone C: The biomechanics of tooth movement. In: Kraus BS, Riedel BA (eds.): Vistas in orthodontics. Lea, Febiger, Philadelphia 197-213, 1962.

19. Dhenain T, Côté F and Coman T: Serotonin and orthodontic tooth movement. Biochimie 161: 73-79, 2019.

20. Asiry MA: Biological aspects of orthodontic tooth movement: A review of literature. Saudi J Biol Sci 25: 1027-1032, 2018

21. Martin Schwarz A: Tissue changes incident to orthodontic tooth movement. Int J Orthodontia Oral Surg Radiography 18: 331-352, 1932.

22. Norevall LI, Forsgren S and Matsson L: Expression of neuropeptides (CGRP, substance P) during and after orthodontic tooth movement in the rat. Eur J Orthod 17: 311-325, 1995.

23. Middleton J, Patterson AM, Gardner L, Schmutz C and Ashton BA: Leukocyte extravasation: Chemokine transport and presentation by the endothelium. Blood 100: 3853-3860, 2002.

24. Lee SK, Pi SH, Kim SH, Min KS, Lee HJ, Chang HS, Kang KH, Kim HR, Shin HI, Lee SK and Kim EC: Substance P regulates macrophage inflammatory protein 3alpha/chemokine $\mathrm{C}$-C ligand 20 (CCL20) with heme oxygenase-1 in human periodontal ligament cells. Clin Exp Immunol 150: 567-575, 2007.

25. Yamaguchi M, Kojima T, Kanekawa M, Aihara N, Nogimura A and Kasai K: Neuropeptides stimulate production of interleukin-1 beta, interleukin-6, and tumor necrosis factor-alpha in human dental pulp cells. Inflamm Res 53: 199-204, 2004

26. KvinnslandIandKvinnsland S: ChangesinCGRP-immunoreactive nerve fibres during experimental tooth movement in rats. Eur J Orthod 12: 320-329, 1990.

27. Ren Y, Hazemeijer H, de Haan B, Qu N and de Vos P: Cytokine profiles in crevicular fluid during orthodontic tooth movement of short and long durations. J Periodontol 78: 453-458, 2007.

28. Kapoor P, Kharbanda OP, Monga N, Miglani R and Kapila S: Effect of orthodontic forces on cytokine and receptor levels in gingival crevicular fluid: A systematic review. Prog Orthod 15: $65,2014$.

29. Teitelbaum SL and Ross FP: Genetic regulation of osteoclast development and function. Nat Rev Genet 4: 638-649, 2003.

30. Xie R, Kuijpers-Jagtman AM and Maltha JC: Osteoclast differentiation during experimental tooth movement by a short-term force application: An immunohistochemical study in rats. Acta Odontol Scand 66: 314-320, 2008.

31. Wada T, Nakashima T, Hiroshi N and Penninger JM: RANKLRANK signaling in osteoclastogenesis and bone disease. Trends Mol Med 12: 17-25, 2006.

32. Azuma Y, Kaji K, Katogi R, Takeshita S and Kudo A: Tumor necrosis factor-alpha induces differentiation of and bone resorption by osteoclasts. J Biol Chem 275: 4858-4864, 2000.

33. Udagawa N, Takahashi N, Jimi E, Matsuzaki K, Tsurukai T, Itoh K, Nakagawa $\mathrm{N}$, Yasuda $\mathrm{H}$, Goto $\mathrm{M}$, Tsuda $\mathrm{E}$, et al: Osteoblasts/stromal cells stimulate osteoclast activation through expression of osteoclast differentiation factor/RANKL but not macrophage colony-stimulating factor: Receptor activator of NF-kappa B ligand. Bone 25: 517-523, 1999.

34. Katagiri T and Takahashi N: Regulatory mechanisms of osteoblast and osteoclast differentiation. Oral Dis 8: 147-159, 2002

35. Thirunavukkarasu K, Halladay DL, Miles RR, Yang X, Galvin RJ, Chandrasekhar S, Martin TJ and Onyia JE: The osteoblast-specific transcription factor Cbfal contributes to the expression of osteoprotegerin, a potent inhibitor of osteoclast differentiation and function. J Biol Chem 275: 25163-25172, 2000.

36. Suda T, Takahashi N and Martin TJ: Modulation of osteoclast differentiation. Endocr Rev 13: 66-80, 1992.

37. Takahashi N, Udagawa N, Akatsu T, Tanaka H, Shionome M and Suda T: Role of colony-stimulating factors in osteoclast development. J Bone Miner Res 6: 977-985, 1991.

38. Liggett W Jr, Shevde N, Anklesaria P, Sohoni S, Greenberger J and Glowacki J: Effects of macrophage colony stimulating factor and granulocyte-macrophage colony stimulating factor on osteoclastic differentiation of hematopoietic progenitor cells. Stem Cells 11: 398-411, 1993. 
39. Boyle WJ, Simonet WS and Lacey DL: Osteoclast differentiation and activation. Nature 423: 337-342, 2003.

40. Tanaka S, Nakamura K, Takahasi N and Suda T: Role of RANKL in physiological and pathological bone resorption and therapeutics targeting the RANKL-RANK signaling system. Immunol Rev 208: 30-49, 2005.

41. Aubin JE and Bonnelye E: Osteoprotegerin and its ligand: A new paradigm for regulation of osteoclastogenesis and bone resorption. Medscape Womens Health 11: 905-913, 2000.

42. Udagawa N, Takahashi N, Yasuda H, Mizuno A, Itoh K, Ueno Y, Shinki T, Gillespie MT, Martin TJ, Higashio K and Suda T: Osteoprotegerin produced by osteoblasts is an important regulator in osteoclast development and function. Endocrinology 141: 3478-3484, 2000.

43. Garlet TP, Coelho U, Silva JS and Garlet GP: Cytokine expression pattern in compression and tension sides of the periodontal ligament during orthodontic tooth movement in humans. Eur J Oral Sci 115: 355-362, 2007.

44. Liu XH, Kirschenbaum A, Yao S and Levine AC: Cross-talk between the interleukin- 6 and prostaglandin E(2) signaling systems results in enhancement of osteoclastogenesis through effects on the osteoprotegerin/receptor activator of nuclear factor-\{kappa B\} (RANK) ligand/RANK system. Endocrinology 146: 1991-1998, 2005.

45. Zhang YH, Heulsmann A, Tondravi MM, Mukherjee A and Abu-Amer Y: Tumor necrosis factor-alpha (TNF) stimulates RANKL-induced osteoclastogenesis via coupling of TNF type 1 receptor and RANK signaling pathways. J Biol Chem 276: 563-568, 2001.

46. Tani-Ishii N, Tsunoda A, Teranaka T and Umemoto T: Autocrine regulation of osteoclast formation and bone resorption by IL-1 alpha and TNF alpha. J Dent Res 78: 1617-1623, 1999.

47. Miyaura C, Inada M, Matsumoto C, Ohshiba T, Uozumi N, Shimizu T and Ito A: An essential role of cytosolic phospholipase A2alpha in prostaglandin E2-mediated bone resorption associated with inflammation. J Exp Med 197: 1303-1310, 2003.

48. Kitaura H, Yoshimatsu M, Fujimura Y, Eguchi T, Kohara H, Yamaguchi A and Yoshida N: An anti-c-Fms antibody inhibits orthodontic tooth movement. J Dent Res 87: 396-400, 2008.

49. Abu-Amer Y, Erdmann J, Alexopoulou L, Kollias G, Ross FP and Teitelbaum SL: Tumor necrosis factor receptors types 1 and 2 differentially regulate osteoclastogenesis. J Biol Chem 275: 27307-27310,2000.

50. Yamasaki K: The role of cyclic AMP, calcium, and prostaglandins in the induction of osteoclastic bone resorption associated with experimental tooth movement. J Dent Res 62: 877-881, 1983

51. Domon S, Shimokawa H, Matsumoto Y, Yamaguchi S and Soma K: In situ hybridization for matrix metalloproteinase-1 and cathepsin $\mathrm{K}$ in rat root-resorbing tissue induced by tooth movement. Arch Oral Biol 44: 907-915, 1999.

52. Apajalahti S, Sorsa T, Railavo S and Ingman T: The in vivo levels of matrix metalloproteinase- 1 and -8 in gingival crevicular fluid during initial orthodontic tooth movement. J Dent Res 82 : 1018-1022, 2003

53. Bonafe-Oliveira L, Faltin RM and Arana-Chavez VE: Ultrastructural and histochemical examination of alveolar bone at the pressure areas of rat molars submitted to continuous orthodontic force. Eur J Oral Sci 111: 410-416, 2003.

54. Krishnan V and Davidovitch Z: Cellular, molecular, and tissue-level reactions to orthodontic force. Am J Orthod Dentofacial Orthop 129: 469.e1-432, 2006.

55. Ducy P, Schinke T and Karsenty G: The osteoblast: A sophisticated fibroblast under central surveillance. Science 289 1501-1504, 2000.

56. Franz-Odendaal TA, Hall BK and Witten PE: Buried alive: How osteoblasts become osteocytes. Dev Dyn 235: 176-190, 2006.

57. Capulli M, Paone R and Rucci N: Osteoblast and osteocyte: Games without frontiers. Arch Biochem Biophys 561: 3-12, 2014.

58. Kundu M, Javed A, Jeon JP, Horner A, Shum L, Eckhaus M, Muenke M, Lian JB, Yang Y, Nuckolls GH, et al: Cbfbeta interacts with Runx 2 and has a critical role in bone development. Nat Genet 32: 639-644, 2002

59. Canalis E, Economides AN and Gazzerro E: Bone morphogenetic proteins, their antagonists, and the skeleton. Endocr Rev 24: 218-235, 2003

60. Chen G, Deng C and Li YP: TGF- $\beta$ and BMP signaling in osteoblast differentiation and bone formation. Int J Biol Sci 8: 272-288, 2012
61. Wu M, Chen G and Li YP: TGF- $\beta$ and BMP signaling in osteoblast, skeletal development, and bone formation, homeostasis and disease. Bone Res 4: 16009, 2016.

62. Lee KS, Hong SH and Bae SC: Both the Smad and p38 MAPK pathways play a crucial role in Runx 2 expression following induction by transforming growth factor-beta and bone morphogenetic protein. Oncogene 21: 7156-7163, 2002.

63. Leivonen SK, Lazaridis K, Decock J, Chantry A, Edwards DR and Kähäri VM: TGF- $\beta$-elicited induction of tissue inhibitor of metalloproteinases (TIMP)-3 expression in fibroblasts involves complex interplay between Smad3, p38 $\alpha$, and ERK1/2. PLoS One 8: e57474, 2013

64. Park-Min KH, Ji JD, Antoniv T, Reid AC, Silver RB, Humphrey MB, Nakamura M and Ivashkiv LB: IL-10 suppresses calcium-mediated costimulation of receptor activator NF-kappa $\mathrm{B}$ signaling during human osteoclast differentiation by inhibiting TREM-2 expression. J Immuno 183: 2444-2455, 2009.

65. Zhang L, Ding Y, Rao GZ and Miao D: Effects of IL-10 and glucose on expression of OPG and RANKL in human periodontal ligament fibroblasts. Braz J Med Biol Res 49: e4324, 2016.

66. Kusumbe AP, Ramasamy SK and Adams RH: Coupling of angiogenesis and osteogenesis by a specific vessel subtype in bone. Nature 507: 323-328, 2014.

67. Sivaraj KK and Adams RH: Blood vessel formation and function in bone. Development 143: 2706-2715, 2016.

68. Park HJ, Baek KH, Lee HL, Kwon A, Hwang HR, Qadir AS, Woo KM, Ryoo HM and Baek JH: Hypoxia inducible factor-1a directly induces the expression of receptor activator of nuclear factor- $\kappa \mathrm{B}$ ligand in periodontal ligament fibroblasts. Mol Cells 31: 573-578, 2011.

69. Dandajena TC, Ihnat MA, Disch B, Thorpe J and Currier GF: Hypoxia triggers a HIF-mediated differentiation of peripheral blood mononuclear cells into osteoclasts. Orthod Craniofac Res 15: 1-9, 2012.

70. Knowles HJ and Athanasou NA: Hypoxia-inducible factor is expressed in giant cell tumour of bone and mediates paracrine effects of hypoxia on monocyte-osteoclast differentiation via induction of VEGF. J Pathol 215: 56-66, 2008.

71. Lee SY, Yoo HI and Kim SH: CCR5-CCL Axis in PDL during orthodontic biophysical force application. J Dent Res 94: 1715-1723, 2015

72. Yang SY, Kim JW, Lee SY, Kang JH, Ulziisaikhan U, Yoo HI, Moon YH, Moon JS, Ko HM, Kim MS and Kim SH: Upregulation of relaxin receptors in the PDL by biophysical force. Clin Oral Investig 19: 657-665, 2015.

73. Lee SY, Moon JS, Yang DW, Yoo HI, Jung JY, Kim OS, Kim MS, Koh JT, Chung HJ and Kim SH: SLPI in periodontal Ligament is not sleepy during biophysical force-induced tooth movement. J Clin Periodontol 48: 528-540, 2021.

74. Dallas SL, Prideaux M and Bonewald LF: The osteocyte: An endocrine cell and more. Endocr Rev 34: 658-690, 2013.

75. Tresguerres FGF, Torres J, López-Quiles J, Hernández G, Vega JA and Tresguerres IF: The osteocyte: A multifunctional cell within the bone. Ann Anat 227: 151422, 2020.

76. Tatsumi S, Ishii K, Amizuka N, Li M, Kobayashi T, Kohno K, Ito M, Takeshita S and Ikeda K: Targeted ablation of osteocytes induces osteoporosis with defective mechanotransduction. Cell Metab 5: 464-475, 2007

77. Goulet GC, Cooper DM, Coombe D and Zernicke RF: Influence of cortical canal architecture on lacunocanalicular pore pressure and fluid flow. Comput Methods Biomech Biomed Engin 11: 379-387, 2008

78. Wang Y,McNamara LM, Schaffler MB and Weinbaum S: A model for the role of integrins in flow induced mechanotransduction in osteocytes. Proc Natl Acad Sci USA 104: 15941-15946, 2007.

79. Phillips JA, Almeida EA, Hill EL, Aguirre JI, Rivera MF, Nachbandi I, Wronski TJ, van der Meulen MC and Globus RK: Role for beta1 integrins in cortical osteocytes during acute musculoskeletal disuse. Matrix Biol 27: 609-618, 2008.

80. Liedert A, Kaspar D, Blakytny R, Claes L and Ignatius A: Signal transduction pathways involved in mechanotransduction in bone cells. Biochem Biophys Res Commun 349: 1-5, 2006.

81. Heino TJ, Hentunen TA and Väänänen HK: Conditioned medium from osteocytes stimulates the proliferation of bone marrow mesenchymal stem cells and their differentiation into osteoblasts. Exp Cell Res 294: 458-468, 2004.

82. Li L, Yang Z, Zhang H, Chen W, Chen M and Zhu Z: Low-intensity pulsed ultrasound regulates proliferation and differentiation of osteoblasts through osteocytes. Biochem Biophys Res Commun 418: 296-300, 2012. 
83. Yellowley CE, Li Z, Zhou Z, Jacobs CR and Donahue HJ: Functional gap junctions between osteocytic and osteoblastic cells. J Bone Miner Res 15: 209-217, 2000.

84. Taylor AF, Saunders MM, Shingle DL, Cimbala JM, Zhou Z and Donahue HJ: Mechanically stimulated osteocytes regulate osteoblastic activity via gap junctions. Am J Physiol Cell Physiol 292: C545-C552, 2007.

85. Cherian PP, Cheng B, Gu S, Sprague E, Bonewald LF and Jiang JX: Effects of mechanical strain on the function of Gap junctions in osteocytes are mediated through the prostaglandin EP2 receptor. J Biol Chem 278: 43146-43156, 2003.

86. Cheng B, Kato Y, Zhao S, Luo J, Sprague E, Bonewald LF and Jiang JX: PGE(2) is essential for gap junction-mediated intercellular communication between osteocyte-like MLO-Y4 cells in response to mechanical strain. Endocrinology 142: 3464-3473, 2001.

87. Kanno T, Takahashi T, Tsujisawa T, Ariyoshi W and Nishihara T: Mechanical stress-mediated Runx2 activation is dependent on Ras/ERK1/2 MAPK signaling in osteoblasts. J Cell Biochem 101: 1266-1277, 2007.

88. Franceschi RT and Xiao G: Regulation of the osteoblast-specific transcription factor, Runx2: Responsiveness to multiple signal transduction pathways. J Cell Biochem 88: 446-454, 2003.

89. Sapir-Koren R and Livshits G: Osteocyte control of bone remodeling: Is sclerostin a key molecular coordinator of the balanced bone resorption-formation cycles? Osteoporos Int 25: 2685-2700, 2014

90.ten Dijke P, Krause C, de Gorter DJ, Löwik CW and van Bezooijen RL: Osteocyte-derived sclerostin inhibits bone formation: Its role in bone morphogenetic protein and Wnt signaling. J Bone Joint Surg Am 90 (Suppl 1): S31-S35, 2008.

91. Galli C, Passeri G and Macaluso GM: Osteocytes and WNT: The mechanical control of bone formation. J Dent Res 89: 331-343, 2010.

92. Kitaura H, Marahleh A, Ohori F, Noguchi T, Shen WR, Qi J, Nara Y,Pramusita A, Kinjo R and Mizoguchi I: Osteocyte-related cytokines regulate osteoclast formation and bone resorption. Int J Mol Sci 21: 5169, 2020.

93. Plotkin LI, Gortazar AR, Davis HM, Condon KW, Gabilondo H, Maycas M, Allen MR and Bellido T: Inhibition of osteocyte apoptosis prevents the increase in osteocytic receptor activator of nuclear factor $\kappa \mathrm{B}$ ligand (RANKL) but does not stop bone resorption or the loss of bone induced by unloading. J Biol Chem 290: 18934-18942, 2015.

94. Lin C, Jiang X, Dai Z, Guo X, Weng T, Wang J, Li Y, Feng G, Gao $X$ and He L: Sclerostin mediates bone response to mechanical unloading through antagonizing Wnt/beta-catenin signaling. J Bone Miner Res 24: 1651-1661, 2009.

95. Cheung WY, Simmons CA and You L: Osteocyte apoptosis regulates osteoclast precursor adhesion via osteocytic IL-6 secretion and endothelial ICAM-1 expression. Bone 50: 104-110, 2012.

96. Al-Dujaili SA, Lau E, Al-Dujaili H, Tsang K, Guenther A and You L: Apoptotic osteocytes regulate osteoclast precursor recruitment and differentiation in vitro. J Cell Biochem 112 2412-2423, 2011.

97. Jilka RL, Noble B and Weinstein RS: Osteocyte apoptosis. Bone 54: 264-271, 2013

98. Wang JH, Thampatty BP, Lin JS and Im HJ: Mechanoregulation of gene expression in fibroblasts. Gene 391: 1-15, 2007.

99. Wang HB, Dembo M, Hanks SK and Wang Y: Focal adhesion kinase is involved in mechanosensing during fibroblast migration. Proc Natl Acad Sci USA 98: 11295-11300, 2001.

100. Warita H, Watarai H and Soma K: Nitric oxide synthase expression is increased by occlusal force in rat periodontal ligament. Orthod Craniofac Res 7: 122-126, 2004.

101. Brandi ML, Hukkanen M, Umeda T, Moradi-Bidhendi N, Bianchi S, Gross SS, Polak JM and MacIntyre I: Bidirectional regulation of osteoclast function by nitric oxide synthase isoforms. Proc Natl Acad Sci USA 92: 2954-2958, 1995.

102. Helfrich MH, Evans DE, Grabowski PS, Pollock JS, Ohshima H and Ralston SH: Expression of nitric oxide synthase isoforms in bone and bone cell cultures. J Bone Miner Res 12: 1108-1115, 1997.

103. Yang S, Guo L, Su Y, Wen J, Du J, Li X, Liu Y, Feng J, Xie Y, Bai Y, et al: Nitric oxide balances osteoblast and adipocyte lineage differentiation via the JNK/MAPK signaling pathway in periodontal ligament stem cells. Stem Cell Res Ther 9: 118, 2018.

104. Watarai H, Warita $\mathrm{H}$ and Soma K: Effect of nitric oxide on the recovery of the hypofunctional periodontal ligament. J Dent Res 83: 338-342, 2004
105. Kaneko K, Miyamoto Y, Tsukuura R, Sasa K, Akaike T, Fujii S, Yoshimura K, Nagayama K, Hoshino M, Inoue S, et al: 8-Nitro-cGMP is a promoter of osteoclast differentiation induced by RANKL. Nitric Oxide 72: 46-51, 2018.

106. Korkmaz Y, Baumann MA, Schröder H, Behrends S, Addicks K, Raab WH and Bloch W: Localization of the NO-cGMP signaling pathway molecules, NOS III-phosphorylation sites, ERK1/2, and Akt/PKB in osteoclasts. J Periodontol 75: 1119-1125, 2004.

107. Dong SS, Williams JP, Jordan SE, Cornwell T and Blair HC: Nitric oxide regulation of cGMP production in osteoclasts. J Cell Biochem 73: 478-487, 1999.

108. Nagayama K, Miyamoto Y, Kaneko K, Yoshimura K, Sasa K, Akaike T, Fujii S, Izumida E, Uyama R, Chikazu D, et al: Production of 8-nitro-cGMP in osteocytic cells and its upregulation by parathyroid hormone and prostaglandin $\mathrm{E}_{2}$. In Vitro Cell Dev Biol Anim 55: 45-51, 2019.

109. Davidovitch Z, Montgomery PC and Shanfeld JL: Cellular localization and concentration of bone cyclic nucleotides in response to acute PTE administration. Calcif Tissue Res 24: 81-91, 1977.

110. Davidovitch Z, Montgomery PC and Shanfeld JL: Guanosine 3',5'-monophosphate in bone: Microscopic visualization by an immuno-histochemical technique. Calcif Tissue Res 24: 73-79, 1977.

111. Davidovitch Z, Montgomery PC, Yost RW and Shanfeld JL: Immuno-histochemical localization of cyclic nucleotides in mineralized tissues: Mechanically-stressed osteoblasts in vivo. Anat Rec 192: 363-373, 1978.

112. Graziani E, Zelent ME and Pelliccioni GA: Biochemical aspects of orthodontic movement: Recent findings and trends. Mondo Ortod 16: 77-84, 1991 (In Italian).

113. Davidovitch Z, Finkelson MD, Steigman S, Shanfeld JL, Montgomery PC and Korostoff E: Electric currents, bone remodeling, and orthodontic tooth movement. II. Increase in rate of tooth movement and periodontal cyclic nucleotide levels by combined force and electric current. Am J Orthod 77: 33-47, 1980.

114. Davidovitch Z, Finkelson MD, Steigman S, Shanfeld JL, Montgomery PC and Korostoff E: Electric currents, bone remodeling, and orthodontic tooth movement. I. The effect of electric currents on periodontal cyclic nucleotides. Am J Orthod 77: 14-32, 1980.

115. Davidovitch Z, Steigman S, Finkelson MD, Yost RW, Montgomery PC, Shanfeld JL and Korostoff E: Immunohistochemical evidence that electric currents increase periosteal cell cyclic nucleotide levels in feline alveolar bone in vivo. Arch Oral Biol 25: 321-327, 1980.

116. Karanth HS and Shetty KS: Orthodontic tooth movement and bioelectricity. Indian J Dent Res 12: 212-221, 2001.

117. Nilforoushan D, Gramoun A, Glogauer M and Manolson MF Nitric oxide enhances osteoclastogenesis possibly by mediating cell fusion. Nitric Oxide 21: 27-36, 2009.

118. Erez A, Nagamani SC, Shchelochkov OA, Premkumar MH, Campeau PM, Chen Y, Garg HK, Li L, Mian A, Bertin TK, et al: Requirement of argininosuccinate lyase for systemic nitric oxide production. Nat Med 17: 1619-1626,2011.

119. Shirazi M, Nilforoushan D, Alghasi H and Dehpour AR: The role of nitric oxide in orthodontic tooth movement in rats. Angle Orthod 72: 211-215, 2002.

120. Akin E, Gurton AU and Olmez H: Effects of nitric oxide in orthodontic tooth movement in rats. Am J Orthod Dentofacial Orthop 126: 608-614, 2004.

121. Armour KE, Van'T Hof RJ, Grabowski PS, Reid DM and Ralston SH: Evidence for a pathogenic role of nitric oxide in inflammation-induced osteoporosis. J Bone Miner Res 14: 2137-2142, 1999.

122. Lin SK, Kok SH, Kuo MY, Lee MS, Wang CC, Lan WH, Hsiao M, Goldring SR and Hong CY: Nitric oxide promotes infectious bone resorption by enhancing cytokine-stimulated interstitial collagenase synthesis in osteoblasts. J Bone Miner Res 18: 39-46, 2003.

123. Cuzzocrea S, Mazzon E, Dugo L, Genovese T, Di Paola R, Ruggeri Z, Vegeto E, Caputi AP, Van De Loo FA, Puzzolo D and Maggi A: Inducible nitric oxide synthase mediates bone loss in ovariectomized mice. Endocrinology 144: 1098-1107, 2003.

124. Gyurko R, Shoji H, Battaglino RA, Boustany G, Gibson FC III, Genco CA, Stashenko P and Van Dyke TE: Inducible nitric oxide synthase mediates bone development and P. gingivalis-induced alveolar bone loss. Bone 36: 472-479, 2005. 
125. Graves DT, Alsulaimani F, Ding Y and Marks SC Jr: Developmentally regulated monocyte recruitment and bone resorption are modulated by functional deletion of the monocytic chemoattractant protein-1 gene. Bone 31: 282-287, 2002.

126. He D, Kou X, Luo Q, Yang R, Liu D, Wang X, Song Y, Cao H, Zeng M, Gan Y and Zhou Y: Enhanced M1/M2 macrophage ratio promotes orthodontic root resorption. J Dent Res 94 129-139, 2015

127. He D, Kou X, Yang R, Liu D, Wang X, Luo Q, Song Y, Liu F, Yan Y, Gan Y and Zhou Y: M1-like macrophage polarization promotes orthodontic tooth movement. J Dent Res 94 1286-1294, 2015.

128. Lee SK, Huang H, Lee SW, Kim KH, Kim KK, Kim HM, Lee ZH and Kim HH: Involvement of iNOS-dependent NO production in the stimulation of osteoclast survival by TNF-alpha. Exp Cell Res 298: 359-368, 2004

129. Kaur S, White S and Bartold M: Periodontal disease as a risk factor for rheumatoid arthritis: A systematic review. JBI Libr Syst Rev 10 (Suppl 42): S1-S12, 2012

130. Wang JW, Yeh CB, Chou SJ, Lu KC, Chu TH, Chen WY, Chien JL, Yen MH, Chen TH and Shyu JF: YC-1 alleviates bone loss in ovariectomized rats by inhibiting bone resorption and inducing extrinsic apoptosis in osteoclasts. J Bone Miner Metab 36: 508-518, 2018

131. van't Hof RJ and Ralston SH: Cytokine-induced nitric oxide inhibits bone resorption by inducing apoptosis of osteoclast progenitors and suppressing osteoclast activity. J Bone Miner Res 12: 1797-1804, 1997

132. Kitaura H, Fujimura Y, Yoshimatsu M, Kohara H, Morita Y, Aonuma T, Fukumoto E, Masuyama R, Yoshida N and TakanoYamamoto T: IL-12- and IL-18-mediated, nitric oxide-induced apoptosis in TNF- $\alpha$-mediated osteoclastogenesis of bone marrow cells. Calcif Tissue Int 89: 65-73, 2011.

133. Kalyanaraman H, Ramdani G, Joshua J, Schall N, Boss GR, Cory E, Sah RL, Casteel DE and Pilz RB: A novel, direct no donor regulates osteoblast and osteoclast functions and increases bone mass in ovariectomized mice. J Bone Miner Res 32: 46-59, 2017

134. Iwaki F, Amano H and Ohura K: Nicorandil inhibits osteoclast differentiation in vitro. Eur J Pharmacol 793: 14-20, 2016.

135. Yaroslavskiy BB, Li Y, Ferguson DJ, Kalla SE, Oakley JI and Blair HC: Autocrine and paracrine nitric oxide regulate attachment of human osteoclasts. J Cell Biochem 91: 962-972, 2004.

136. Yaroslavskiy BB, Zhang Y, Kalla SE, García Palacios V, Sharrow AC, Li Y, Zaidi M, Wu C and Blair HC: NO-dependent osteoclast motility: Reliance on cGMP-dependent protein kinase I and VASP. J Cell Sci 118: 5479-5487, 2005.

137. Yaroslavskiy BB, Turkova I, Wang Y, Robinson LJ and Blair HC: Functional osteoclast attachment requires inositol-1,4,5-trisphosphate receptor-associated cGMP-dependent kinase substrate. Lab Invest 90: 1533-1542, 2010.

138. Fukada SY, Silva TA, Saconato IF, Garlet GP, Avila-Campos MJ, Silva JS and Cunha FQ: iNOS-derived nitric oxide modulates infection-stimulated bone loss. J Dent Res 87: 1155-1159, 2008.

139. Silva MJ, Sousa LM, Lara VP, Cardoso FP, Júnior GM, Totola AH, Caliari MV, Romero OB, Silva GA, Ribeiro-Sobrinho AP and Vieira LQ: The role of iNOS and PHOX in periapical bone resorption. J Dent Res 90: 495-500, 2011.

140. Zheng H, Yu X, Collin-Osdoby P and Osdoby P: RANKL stimulates inducible nitric-oxide synthase expression and nitric oxide production in developing osteoclasts. An autocrine negative feedback mechanism triggered by RANKL-induced interferon-beta via NF-kappaB that restrains osteoclastogenesis and bone resorption. J Biol Chem 281: 15809-15820, 2006

141. Otsuka E, Hirano K, Matsushita S, Inoue A, Hirose S, Yamaguchi A and Hagiwara $\mathrm{H}$ : Effects of nitric oxide from exogenous nitric oxide donors on osteoblastic metabolism. Eur J Pharmacol 349: 345-350, 1998.

142. Hikiji H, Shin WS, Oida S, Takato T, Koizumi T and Toyo-oka T: Direct action of nitric oxide on osteoblastic differentiation. FEBS Lett 410: 238-242, 1997.

143. Inoue A, Hiruma Y, Hirose S, Yamaguchi A and Hagiwara $\mathrm{H}$ Reciprocal regulation by cyclic nucleotides of the differentiation of rat osteoblast-like cells and mineralization of nodules. Biochem Biophys Res Commun 215: 1104-1110, 1995.

144. Pal S, Rashid M, Singh SK, Porwal K, Singh P, Mohamed R, Gayen JR, Wahajuddin M and Chattopadhyay N: Skeletal restoration by phosphodiesterase 5 inhibitors in osteopenic mice: Evidence of osteoanabolic and osteoangiogenic effects of the drugs. Bone 135: 115305, 2020.
145. Mancini L, Moradi-Bidhendi N, Becherini L, Martineti V and MacIntyre I: The biphasic effects of nitric oxide in primary rat osteoblasts are cGMP dependent. Biochem Biophys Res Commun 274: 477-481, 2000.

146. Zaragoza C, López-Rivera E, García-Rama C, Saura M, Martínez-Ruíz A, Lizarbe TR, Martín-de-Lara F and Lamas S: Cbfa-1 mediates nitric oxide regulation of MMP-13 in osteoblasts. J Cell Sci. 119: 1896-1902, 2006.

147. Armour KE, Armour KJ, Gallagher ME, Gödecke A, Helfrich MH, Reid DM and Ralston SH: Defective bone formation and anabolic response to exogenous estrogen in mice with targeted disruption of endothelial nitric oxide synthase. Endocrinology 142: 760-766, 2001.

148. Ma P, Gu B, Xiong W, Tan B, Geng W, Li J and Liu H: Glimepiride promotes osteogenic differentiation in rat osteoblasts via the $\mathrm{PI} 3 \mathrm{~K} / \mathrm{Akt} / \mathrm{eNOS}$ pathway in a high glucose microenvironment. PLoS One 9: e112243, 2014.

149. Almeida M, Han L, Bellido T, Manolagas SC and Kousteni S: Wnt proteins prevent apoptosis of both uncommitted osteoblast progenitors and differentiated osteoblasts by beta-catenin-dependent and -independent signaling cascades involving Src/ERK and phosphatidylinositol 3-kinase/AKT. J Biol Chem 280: 41342-41351, 2005.

150. Wimalawansa SJ: Rationale for using nitric oxide donor therapy for prevention of bone loss and treatment of osteoporosis in humans. Ann N Y Acad Sc 1117: 283-297, 2007.

151. Willems HM, van den Heuvel EG, Carmeliet G, Schaafsma A, Klein-Nulend J and Bakker AD: VDR dependent and independent effects of 1,25-dihydroxyvitamin D3 on nitric oxide production by osteoblasts. Steroids 77: 126-131, 2012

152. Yan L, Yinghui T, Bo Y, Gang Z, Xian X and Lu Z: Effect of calcitonin gene-related peptide on nitric oxide production in osteoblasts: An experimental study. Cell Biol Int 35: 757-765, 2011.

153. Li Y, Tan Y, Zhang G, Yang B and Zhang J: Effects of calcitonin gene-related peptide on the expression and activity of nitric oxide synthase during mandibular bone healing in rabbits: An experimental study. J Oral Maxillofac Surg 67: 273-279, 2009.

154. O'Shaughnessy MC, Polak JM, Afzal F, Hukkanen MV, Huang P, MacIntyre I and Buttery LD: Nitric oxide mediates 17beta-estradiol-stimulated human and rodent osteoblast proliferation and differentiation. Biochem Biophys Res Commun 277: 604-610, 2000.

155. Yang JY, Park MY, Park SY, Yoo HI, Kim MS, Kim JH, Kim WJ and Jung JY: Nitric oxide-induced autophagy in MC3T3-E1 cells is associated with cytoprotection via ampk activation. Korean J Physiol Pharmacol 19: 507-514, 2015.

156. Joshua J, Schwaerzer GK, Kalyanaraman H, Cory E, Sah RL, Li M, Vaida F, Boss GR and Pilz RB: Soluble guanylate cyclase as a novel treatment target for osteoporosis. Endocrinology 155: 4720-4730, 2014.

157. Marathe N, Rangaswami H, Zhuang S, Boss GR and Pilz RB: Pro-survival effects of $17 \beta$-estradiol on osteocytes are mediated by nitric oxide/cGMP via differential actions of cGMP-dependent protein kinases I and II. J Biol Chem 287: 978-988, 2012.

158. Joshua J, Kalyanaraman H, Marathe N and Pilz RB: Nitric oxide as a mediator of estrogen effects in osteocytes. Vitam Horm 96: 247-263, 2014

159. Lee SK, Choi HI, Yang YS, Jeong GS, Hwang JH, Lee SI, Kang KH, Cho JH, Chae JM, Lee SK, et al: Nitric oxide modulates osteoblastic differentiation with heme oxygenase-1 via the mitogen activated protein kinase and nuclear factor-kappaB pathways in human periodontal ligament cells. Biol Pharm Bull 32: 1328-1334, 2009.

160. d'Alessandro L, Petrini M, Ferrante M, Di Marco S, Trubiani O and Spoto G: Cyclic nucleotide phosphodiesterase activity in stem cells of human periodontal ligament (PDL-MSCs) before and after osteogenic induction. Oral Surg Oral Med Oral Pathol Oral Radiol 116: e317-e323, 2013.

161. Tang J, Wu T, Xiong J, Su Y, Zhang C, Wang S, Tang Z and Liu Y: Porphyromonas gingivalis lipopolysaccharides regulate functions of bone marrow mesenchymal stem cells. Cell Prolif 48: 239-248, 2015.

162. Seo T, Cha S, Woo KM, Park YS, Cho YM, Lee JS and Kim TI: Synergic induction of human periodontal ligament fibroblast cell death by nitric oxide and N-methyl-D-aspartic acid receptor antagonist. J Periodontal Implant Sci 41: 17-22, 2011.

163. Reher P, Harris M, Whiteman M, Hai HK and Meghji S: Ultrasound stimulates nitric oxide and prostaglandin E2 production by human osteoblasts. Bone 31: 236-241, 2002. 
164. Wittkowske C, Reilly GC, Lacroix D and Perrault CM: In vitro bone cell models: Impact of fluid shear stress on bone formation. Front Bioeng Biotechnol 4: 87, 2016.

165. Shibata K, Yoshimura Y, Kikuiri T, Hasegawa T, Taniguchi Y, Deyama Y, Suzuki K and Iida J: Effect of the release from mechanical stress on osteoclastogenesis in RAW264.7 cells. Int J Mol Med 28: 73-79, 2011.

166. van der Meijden K, Bakker AD, van Essen HW, Heijboer AC, Schulten EA, Lips P and Bravenboer N: Mechanical loading and the synthesis of 1,25(OH)2D in primary human osteoblasts. J Steroid Biochem Mol Biol 156: 32-39, 2016.

167. Diniz P, Soejima K and Ito G: Nitric oxide mediates the effects of pulsed electromagnetic field stimulation on the osteoblast proliferation and differentiation. Nitric Oxide 7: 18-23, 2002.

168. Pathak JL, Bravenboer N, Luyten FP, Verschueren P, Lems WF, Klein-Nulend $\mathrm{J}$ and Bakker A: Mechanical loading reduces inflammation-induced human osteocyte-to-osteoclast communication. Calcif Tissue Int 97: 169-178, 2015.

169. Premaraj S, Souza I and Premaraj T: Focal adhesion kinase mediates $\beta$-catenin signaling in periodontal ligament cells. Biochem Biophys Res Commun 439: 487-492, 2013.

170. Nakago-Matsuo C, Matsuo T and Nakago T: Basal nitric oxide production is enhanced by hydraulic pressure in cultured human periodontal ligament fibroblasts. Am J Orthod Dentofacial Orthop 117: 474-478, 2000.

171. Kraft DC, Bindslev DA, Melsen B, Abdallah BM, Kassem M and Klein-Nulend J: Mechanosensitivity of dental pulp stem cells is related to their osteogenic maturity. Eur J Oral Sci 118: 29-38, 2010.

172. Kraft DC, Bindslev DA, Melsen B and Klein-Nulend J: Human dental pulp cells exhibit bone cell-like responsiveness to fluid shear stress. Cytotherapy 13: 214-226, 2011.

173. Santos A, Bakker AD, Zandieh-Doulabi B, de BlieckHogervorst JM and Klein-Nulend J: Early activation of the beta-catenin pathway in osteocytes is mediated by nitric oxide, phosphatidyl inositol-3 kinase/Akt, and focal adhesion kinase. Biochem Biophys Res Commun 391: 364-369, 2010.

174. Santos A, Bakker AD, Zandieh-Doulabi B, Semeins CM and Klein-Nulend J: Pulsating fluid flow modulates gene expression of proteins involved in Wnt signaling pathways in osteocytes. J Orthop Res 27: 1280-1287, 2009.

175. Rangaswami H, Schwappacher R, Tran T, Chan GC, Zhuang S, Boss GR and Pilz RB: Protein kinase $G$ and focal adhesion kinase converge on $\mathrm{Src} / \mathrm{Akt} / \mathrm{\beta}$-catenin signaling module in osteoblast mechanotransduction. J Biol Chem 287: 21509-21519, 2012.

176. Rangaswami H, Schwappacher R, Marathe N, Zhuang S, Casteel DE, Haas B, Chen Y, Pfeifer A, Kato H, Shattil S, et al: Cyclic GMP and protein kinase G control a Src-containing mechanosome in osteoblasts. Sci Signal 3: ra91, 2010.

177. Rangaswami H, Marathe N, Zhuang S, Chen Y, Yeh JC Frangos JA, Boss GR and Pilz RB: Type II cGMP-dependent protein kinase mediates osteoblast mechanotransduction. J Biol Chem 284: 14796-14808, 2009.

178. Willems HM, van den Heuvel EG, Castelein S, Buisman JK, Bronckers AL, Bakker AD and Klein-Nulend J: Fluoride inhibits the response of bone cells to mechanical loading. Odontology 99: 112-118, 2011

179. Vezeridis PS, Semeins CM, Chen Q and Klein-Nulend J: Osteocytes subjected to pulsating fluid flow regulate osteoblast proliferation and differentiation. Biochem Biophys Res Commun 348: 1082-1088, 2006.

180. Tan SD, de Vries TJ, Kuijpers-Jagtman AM, Semeins CM, Everts V and Klein-Nulend J: Osteocytes subjected to fluid flow inhibit osteoclast formation and bone resorption. Bone 41: 745-751, 2007.

181. Bakker AD, Soejima K, Klein-Nulend J and Burger EH: The production of nitric oxide and prostaglandin $\mathrm{E}(2)$ by primary bone cells is shear stress dependent. J Biomech 34: 671-677, 2001

182. Tan SD, Bakker AD, Semeins CM, Kuijpers-Jagtman AM and Klein-Nulend J: Inhibition of osteocyte apoptosis by fluid flow is mediated by nitric oxide. Biochem Biophys Res Commun 369: $1150-1154,2008$

183. Juffer P, Jaspers RT, Lips P, Bakker AD and Klein-Nulend J: Expression of muscle anabolic and metabolic factors in mechanically loaded MLO-Y4 osteocytes. Am J Physiol Endocrinol Metab 302: E389-E395, 2012

184. Furumatsu T, Shen ZN, Kawai A, Nishida K, Manabe H, Oohashi T, Inoue $\mathrm{H}$ and Ninomiya Y: Vascular endothelia growth factor principally acts as the main angiogenic factor in the early stage of human osteoblastogenesis. J Biochem 133 633-639, 2003.
185. Fisslthaler B, Loot AE, Mohamed A, Busse R and Fleming I: Inhibition of endothelial nitric oxide synthase activity by proline-rich tyrosine kinase 2 in response to fluid shear stress and insulin. Circ Res 102: 1520-1528, 2008.

186. Ghimire K, Altmann HM, Straub AC and Isenberg JS: Nitric oxide: What's new to NO? Am J Physiol Cell Physiol 312 C254-C262, 2017

187. Zaman G, Pitsillides AA, Rawlinson SC, Suswillo RF, Mosley JR, Cheng MZ, Platts LA, Hukkanen M, Polak JM and Lanyon LE: Mechanical strain stimulates nitric oxide production by rapid activation of endothelial nitric oxide synthase in osteocytes. J Bone Miner Res 14: 1123-1131, 1999.

188. Dimmeler S, Fleming I, Fisslthaler B, Hermann C, Busse R and Zeiher AM: Activation of nitric oxide synthase in endothelial cells by Akt-dependent phosphorylation. Nature 399: 601-605, 1999.

189. Klein-Nulend J, Helfrich MH, Sterck JG, MacPherson H, Joldersma M, Ralston SH, Semeins CM and Burger EH: Nitric oxide response to shear stress by human bone cell cultures is endothelial nitric oxide synthase dependent. Biochem Biophys Res Commun 250: 108-114, 1998.

190. Bakker AD, Huesa C, Hughes A, Aspden RM, van't Hof RJ, Klein-Nulend $\mathrm{J}$ and Helfrich $\mathrm{MH}$ : Endothelial nitric oxide synthase is not essential for nitric oxide production by osteoblasts subjected to fluid shear stress in vitro. Calcif Tissue Int 92: 228-239, 2013.

191. Das-Gupta V, Williamson RA and Pitsillides AA: Expression of endothelial nitric oxide synthase protein is not necessary for mechanical strain-induced nitric oxide production by cultured osteoblasts. Osteoporos Int 23: 2635-2647, 2012.

192. Hou CH, Lin J, Huang SC, Hou SM and Tang CH: Ultrasound stimulates NF-kappaB activation and iNOS expression via the Ras/Raf/MEK/ERK signaling pathway in cultured preosteoblasts. J Cell Physiol 220: 196-203, 2009.

193. Padilla F, Puts R, Vico L and Raum K: Stimulation of bone repair with ultrasound: A review of the possible mechanic effects. Ultrasonics 54: 1125-1145, 2014.

194. Kusuyama J, Bandow K, Ohnishi T, Hisadome M, Shima K, Semba I and Matsuguchi T: Osteopontin inhibits osteoblast responsiveness through the down-regulation of focal adhesion kinase mediated by the induction of low-molecular weight protein tyrosine phosphatase. Mol Biol Cell 28: 1326-1336, 2017.

195. Aggarwal H, Pathak P, Singh P, Gayen JR, Jagavelu K and Dikshit M: Systemic insulin resistance and metabolic perturbations in chow fed inducible nitric oxide synthase knockout male mice: Partial reversal by nitrite supplementation. Antioxidants (Basel) 9: 736, 2020 .

196. Foster MW, Hess DT and Stamler JS: Protein S-nitrosylation in health and disease: A current perspective. Trends Mol Med 15: 391-404, 2009.

197. Huang B, Chen SC and Wang DL: Shear flow increases S-nitrosylation of proteins in endothelial cells. Cardiovase Res 83: 536-546, 2009.

198. Yoo SK, Warita H and Soma K: Duration of orthodontic force affecting initial response of nitric oxide synthase in rat periodontal ligaments. J Med Dent Sci 51: 83-88, 2004.

199. Nilforoushan D and Manolson MF: Expression of nitric oxide synthases in orthodontic tooth movement. Angle Orthod 79: 502-508, 2009.

200. Tan SD, Xie R, Klein-Nulend J, van Rheden RE, Bronckers AL, Kuijpers-Jagtman AM, Von den Hoff JW and Maltha JC: Orthodontic force stimulates eNOS and iNOS in rat osteocytes. J Dent Res 88: 255-260, 2009

201. Baloul SS: Osteoclastogenesis and osteogenesis during tooth movement. Front Oral Bio 18: 75-79, 2016

202. D'Attillio M, Di Maio F, D'Arcangela C, Filippi MR, Felaco M, Lohinai Z, Festa F and Perinetti G: Gingival endothelial and inducible nitric oxide synthase levels during orthodontic treatment: A cross-sectional study. Angle Orthod 74: 851-858, 2004.

203. Ford H, Suri S, Nilforoushan D, Manolson M and Gong SG Nitric oxide in human gingival crevicular fluid after orthodontic force application. Arch Oral Biol 59: 1211-1216, 2014

204. Topal SC, Tuncer BB, Elgun S, Erguder I and Ozmeric N: Levels of cytokines in gingival crevicular fluid during rapid maxillary expansion and the subsequent retention period. J Clin Pediatr Dent 43: 137-143, 2019.

205. Ozel N, Aksoy A, Kirzioglu FY, Doguc DK and Aksoy TA: Evaluation of interleukin-1 $\beta$ level and oxidative status in gingival crevicular fluid during rapid maxillary expansion. Arch Oral Biol 90: 74-79, 2018. 
206. Atuğ Özcan SS, Ceylan I, Ozcan E, Kurt N, Dağsuyu IM and Canakçi CF: Evaluation of oxidative stress biomarkers in patients with fixed orthodontic appliances. Dis Markers 2014: 597892, 2014

207. Hayashi K, Igarashi K, Miyoshi K, Shinoda H and Mitani H: Involvement of nitric oxide in orthodontic tooth movement in rats. Am J Orthod Dentofacial Orthop 122: 306-309, 2002.

208. Rausch-Fan X and Matejka M: From plaque formation to periodontal disease, is there a role for nitric oxide? Eur J Clin Invest 31: 833-835, 2001.

209. de Farias JO, de Freitas Lima SM and Rezende TMB: Physiopathology of nitric oxide in the oral environment and its biotechnological potential for new oral treatments: A literature review. Clin Oral Investig 24: 4197-4212, 2020.

210. Qu XM, Wu ZF, Pang BX, Jin LY, Qin LZ and Wang SL: From Nitrate to Nitric Oxide: The role of salivary glands and oral bacteria. J Dent Res 95: 1452-1456, 2016.

211. Carossa S, Pera P, Doglio P, Lombardo S, Colagrande P, Brussino L, Rolla G and Bucca C: Oral nitric oxide during plaque deposition. Eur J Clin Invest 31: 876-879, 2001.
212. Khodaii Z, Mehrabani M, Rafieian N, Najafi-Parizi GA, Mirzaei A and Akbarzadeh R: Altered levels of salivary biochemical markers in periodontitis. Am J Dent 32: 183-186, 2019.

213. Sundar NM, Krishnan V, Krishnaraj S, Hemalatha VT and Alam MN: Comparison of the salivary and the serum nitric oxide levels in chronic and aggressive periodontitis: A biochemical study. J Clin Diagn Res 7: 1223-1227, 2013.

214. Parwani SR, Chitnis PJ and Parwani RN: Salivary nitric oxide levels in inflammatory periodontal disease-a case-control and interventional study. Int J Dent Hyg 10: 67-73, 2012.

215. Sokos D, Everts V and de Vries TJ: Role of periodontal ligament fibroblasts in osteoclastogenesis: A review. J Periodontal Res 50: 152-159, 2015.

This work is licensed under a Creative Commons Attribution-NonCommercial-NoDerivatives 4.0 International (CC BY-NC-ND 4.0) License. 